\title{
振動特性を対象としたレベルセット法に基づく機械構造物の最適化*
}

\author{
山㠃 慎太郎*1, 西 脇 眞 二*1, \\ 泉 井一 浩*1, 吉 村允 孝*2
}

\section{Structural Optimization of Mechanical Structures Targeting Vibration Characteristics Based on the Level Set Method}

\author{
Shintaro YAMASAKI*3, Shinji NISHIWAKI, \\ Kazuhiro IZUI and Masataka YOSHIMURA \\ ${ }^{* 3}$ Department of Aeronautics and Astronautics, Kyoto University, \\ Yoshida-honmachi, Sakyo-ku, Kyoto-shi, Kyoto, 606-8501 Japan
}

\begin{abstract}
Vibration characteristics such as eigenfrequencies and eigenmodes are crucial factors that determine the dynamic performance of mechanical structures, and high performance structures that function dynamically can be designed by appropriately specifying such vibration characteristics. This paper proposes a structural optimization method for obtaining mechanical structures having specified vibration characteristics, based on the level set method. First, the basic details of a structural optimization method using the level set method, which can be applied to dynamic problems, are briefly discussed. Next, optimization problems that address the maximum eigenfrequencies, and the matching of eigenfrequencies with target values, are formulated. A new optimization algorithm based on the level set method is constructed, where a newly improved geometric reinitialization scheme is used for re-initializing a level set function, based on a zero level set surface. Using the proposed optimization algorithm, both the solving of the eigenvalue problem and the updating of the level set function are performed using the FEM, where non-structural meshes can easily be configured. Finally, several design examples are provided to confirm the usefulness of the proposed structural optimization method.
\end{abstract}

Key Words: Optimum Design, Structural Analysis, Vibration of Continuous System, Sensitivity Analysis, Finite Element Method

\section{1. 緒言}

機械構造物の動特性, 特に振動特性は構造物の動的 な性能を決定づける重要な特性である，例えば，最低 次の固有振動数は, 比較的低い振動数領域における動 的な安定性を示す評価尺度で，この値をできるだけ大 きな值とすることにより, 高い動的な安定性を得るこ とができる(1)(2).さらに, それより高い振動数領域で は，共振現象による不安定性を回避するために，固有 振動数を外部励起荷重の振動数と一致しないように設 計する。

このような構造の安定性を確保する設計に対して, 機械構造物の共振現象を積極的に利用することによ り，より高い動的機能をもつ機械構造物を設計するこ とも可能である. 代表的な例として, 機械式レゾネー 夕(3)やバイブロモータ(4)があげられる。これらの機 能構造物は，ある指定された固有振動数や固有振動モ ードを持つことにより，所定の機能を実現する。

以上のような振動特性を対象とした機械構造物の最

\footnotetext{
* 原稿受付 2007 年 9 月 7 日.

*1 正員, 京都大学大学院工学研究科(画606-8501 京都市左京 区吉田本町).

*2 正員, フェロー, 京都大学大学院工学研究科.

E-mail : beetle@ ruby.dti.ne.jp
}

適設計については, 現在までにトポロジー最適化 ${ }^{(5)} に$ づいた方法(1)(2)や，力法に基づいた方法 ${ }^{(6)}$ が提案され ている、しかし，これらは基本的には，固有振動数最 大化もしくは質量最小化を対象とした場合のみの最適 構造を得るにとどまり, 前述の, 機械構造物の共振現 象を積極的に利用することにより得られる，より高い 動的機能をもつ構造の創出には至っていない.これに 対して, Nishiwaki ら (7)や Tcherniak ${ }^{(8)}$ は, 周期荷重 を負荷した場合の出力変位の最大化を行うことによ り，機械式レゾネータなどのより高い動的な機能をも つ機械構造を創出している.しかし，この方法におい ては，目標関数の極度の多峰性により，グレースケー ルを含まない物理的に意味のある最適構造を得ること が非常に難しい欠点をもつ. Maeda ら(9)は,この問 題を解決しながら, さらに高度な振動特性をもつ最適 構造を創成する方法として, 目的とする固有振動数と 固有振動モードを設定する際に, 適切な剛性を付加す ることによりグレースケールを回避する方法を提案し ている.

しかし, この方法では, 最適構造が剛性の付加方法 に左右される問題点をもち, 抜本的な解決には至って いない.

他方, グレースケールなどの数值的問題を抜本的に 
解決しながら構造の形状と形態の変更を可能とする新 しい形状最適化の方法として, レベルセット法に基づ く構造最適化法(10) (12) が提案され, 振動問題へも適用 されつつある.この方法は, 外形形状を一次元高位の レベルセット関数を用いて表現し, 最適化問題の定式 化に基づいてレベルセット関数を更新することにより 形状変更を行い,さらにトポロジカルデリバティブ(13) の導入により, 構造の形状と形態を同時に変更可能と する. Allaire と Jouve ${ }^{(14)}$ は, 最初に最低次の固有振 動数最大化の場合について方法論を提案した。しか し, 特定の固有振動数を持つ構造を求める問題などの 他の振動問題への展開はない. また, Osher と Santosa ${ }^{(15)}$ は, 質量密度のみを設計変数とする特定の 設定条件下に扔いて, 膜の固有振動数の最適化を目的 とした方法論を構築しているが, 一般的な機械構造物 を対象とした方法論への展開はなされていない.さら に, これらの方法では, レベルセット関数を差分法に より更新しており，実用的な設計問題への適用にはメ ッシュ生成上の制約を持つうえ, トポロジカルデリバ ティブについての議論もなく, さらに振動問題特有の ローカライズドモード(16) の問題に関する議論もされ ていない.

そこで本研究では，振動特性の適正化を目的とした 機械構造物の実用的な最適設計法を, レベルセット法 と有限要素法に基づき構築する。すなわち, より動的 に安定な機械構造物を得るために, 最低次の固有振動 数最大化問題, さらに, 共振現象を積極的に利用する ことにより実現可能な, より高い動的機能をもつ機械 構造物を得るために, 特定の固有振動数を持つ構造を 求める問題を対象として,レベルセット関数の更新を 有限要素法により行い, トポロジカルデリバティブを 用いて形態を変更可能な, 新しい形状最適化法を開発 する.なお, 特定の固有振動数を持つ構造を求める場 合には, 構造に必要とされる動的機能から, その動的 機能を実現するために利用すべき振動モードを選択 し, その振動モードに関連する固有振動数を特定して, 目的值への一致を行うものとする. 以下 2 章では, レ ベルセット法に基づく形状最適化の考え方を説明す る. 次に, 上述の二つの問題について, 目的汎関数を 定式化するとともに，この目的汎関数を用いて最適化 問題を定式化し，トポロジカルデリバティブを定式化 する. 3 章では, 最適化問題の定式化に基づき, 有限 要素法を用いた最適化アルゴリズムを開発する。そし て,レベルセット関数の再初期化法については, 筆者 ら(17) が提案する幾何学的配置に基づく再初期化法を, より実装が容易な方法に改善し, 具体的な手続きを作
成する.さらに, 形状表現に利用するへビサイド関数 の近似法に改良を加えることにより, ローカライズド モードを回避する方法も提案する. 最後に 4 章では, 簡単な数值例により本報で提唱する方法論の妥当性を 検証する。

\section{2. 定式 化}

$2 \cdot 1$ レベルセット法に基づく構造最適化 レベ ルセット法では, 物体の形状を一次元高位のレベルセ ット関数を用いて表現する。すなわち, 次式に示すよ うに, 物体領域(物体により占められている領域)にお いて正, 空洞領域(物体により占められていない領域) において負, 物体境界においてゼロとなるレベルセッ 卜関数 $\phi(\boldsymbol{x})$ を用いて物体の形状を表現する。

$$
\left.\begin{array}{ll}
\phi(\boldsymbol{x})>0, & \boldsymbol{x} \in \Omega^{+} \\
\phi(\boldsymbol{x})=0, & \boldsymbol{x} \in \partial \Omega \\
\phi(\boldsymbol{x})<0, & \boldsymbol{x} \in \Omega^{-}
\end{array}\right\}
$$

ここで, $\Omega^{+}$は物体領域, $\Omega^{-}$は空洞領域, $\partial \Omega$ は物体 境界である。レベルセット法に基づく最適化法におい ては, 物体領域と空洞領域が混在する設計領域 $D$ 内 の物体形状をレベルセット関数を用いて表現し, 最適 化過程に扔いてレベルセット関数を更新することによ り，最適化を行う.

今, 仮想的な時間 $t$ を導入し, 最適化過程における レベルセット関数の変動を, 以下に示すハミルトンー ヤコビ方程式で表現する.

$$
\frac{\partial \phi(\boldsymbol{x})}{\partial t}+\boldsymbol{V}(\boldsymbol{x}) \cdot \nabla \phi(\boldsymbol{x})=0
$$

ここで, $\boldsymbol{V}(\boldsymbol{x})$ はレベルセット関数の変動速度であ る. 変動速度 $V(x)$ について, レベルセット関数の等 位面に対する法線成分を $V_{N}(\boldsymbol{x})$ とすると，次式が成 り立つ.

$$
V_{N}(\boldsymbol{x})=\boldsymbol{V}(\boldsymbol{x}) \cdot \frac{\nabla \phi(\boldsymbol{x})}{|\nabla \phi(\boldsymbol{x})|}
$$

したがって式(2), 式(3)より, 次式が得られる。

$$
\frac{\partial \phi(\boldsymbol{x})}{\partial t}+V_{N}(\boldsymbol{x})|\nabla \phi(\boldsymbol{x})|=0 \text {. }
$$

レベルセット法に基づく最適化において, $V_{N}(\boldsymbol{x})$ は最 適化問題の定式化に基づいて得られる, 外形形状感度 である。さらに、レベルセット関数が物体境界に対す る符号付き距離関数の性質を常に保持できれば, $|\nabla \phi(x)|=1$ が成り立つため, 式(4)上り, 次式が得ら れる.

$$
\frac{\partial \phi(\boldsymbol{x})}{\partial t}+V_{N}(\boldsymbol{x})=0
$$

通常のレベルセット関数の更新に扔いては, 更新後に 距離関数の性質である $|\nabla \phi(x)|=1$ が失われるため, 
式 (4)を解いて, レベルセット関数を更新する.しか し, 式 ( 4 )を数值解析法で解くことは容易ではなく, 特に有限要素法を用いた場合には, Petrov-Galerkin 法などの方法が必要となり, 更新が極めて複雑にな る(18).これに対して, 更新後に常にレベルセット関数 を再初期化すれば，更新前後において，式（5）が成立 すると言える。そこで, 本研究では, レベルセット関 数を更新する毎に再初期化を行い, 常に $|\nabla \phi(x)|=1$ が成立するようにしながら, 式（5）に基づきレベルセ ット関数を更新する。なお，以下の定式化においては， 符号付き距離関数をレベルセット関数として用いるこ とを前提とする。

$2 \cdot 2$ 構造最適化問題の定式化 設計領域 $D$ にお いて, 制約汎関数 $G_{\phi}$ の制約のもと, 目的汎関数 $F_{\phi}$ を 最小化する次式の最適化問題を考える.

Minimize $F_{\phi}$

Subject to $G_{\phi}-G_{\max } \leq 0$

ここで, $G_{\max }$ は $G_{\phi}$ の上限值である.さらに，目的汎 関数の変分 $\delta F_{\phi}$ と制約汎関数の変分. $\delta G_{\phi}$ は, レベル セット関数の任意の変分 $\delta \phi$ を用いて, 次式のように 表されるものとする.

$$
\begin{aligned}
& \delta F_{\phi}=\int_{D} f(\phi(\boldsymbol{x})) \delta \phi \mathrm{d} \Omega . \\
& \delta G_{\phi}=\int_{D} g(\phi(\boldsymbol{x})) \delta \phi \mathrm{d} \Omega
\end{aligned}
$$

ここで, $f(\phi(\boldsymbol{x}))$ と $g(\phi(\boldsymbol{x}))$ は, それぞれ目的汎関数 と制約汎関数の変分を記述するための $\phi(x)$ の関数で ある。

次に，上の最適化問題の $\mathrm{KKT}$ 条件を導く。まず， ラグランジェアン $\bar{F}_{\phi}$ をラグランジュ乗数 $\lambda$ を用いて, 次式のように表す.

$$
\bar{F}_{\phi}=F_{\phi}+\lambda\left(G_{\phi}-G_{\max }\right)
$$

上式を用いて $\mathrm{KKT}$ 条件を導けば，次式となる.

$$
\delta \bar{F}_{\phi}=0, \quad \lambda\left(G_{\phi}-G_{\max }\right)=0
$$$$
\lambda \geq 0, \quad G_{\phi}-G_{\max } \leq 0
$$

ここで， $\delta \bar{F}_{\phi}$ は $\bar{F}_{\phi}$ の変分である.この KKT 条件を 満足するレベルセット関数を求めれば, 最適解の候補 になる。さらに, 式( 8 ), 式(9), 式(10)から, $\delta \bar{F}_{\phi}$ は,

$$
\delta \bar{F}_{\phi}=\int_{D}[f(\phi(\boldsymbol{x}))+\lambda g(\phi(\boldsymbol{x}))] \delta \phi \mathrm{d} \Omega
$$

となるが， $\delta \phi$ は，レベルセット関数の任意の変分であ るので, $\delta \bar{F}_{\phi}=0$ が成り立つということは, 設計領域全 域において次式が成り立つということと等価になる.

$$
f(\phi(\boldsymbol{x}))+\lambda g(\phi(\boldsymbol{x}))=0
$$

したがって, 式(11)を満足する $\lambda$ について, 式(13)を 満たすレベルセット関数が最適解となるが, これを直
接求めるのは困難である。そこで, 仮想的な時間 $t$ を 導入し, 次式に示す偏微分方程式を解くことにより最 適解を求める。

$$
\frac{\partial \phi(\boldsymbol{x})}{\partial t}+f(\phi(\boldsymbol{x}))+\lambda g(\phi(\boldsymbol{x}))=0
$$

ここで, 最適化過程における微小な時間変分を $\delta t$ と おくと, $\delta t$ に対応するレベルセット関数の変分 $\delta \phi$ は 次式により与えられる.

$$
\delta \phi=\frac{\partial \phi(x)}{\partial t} \delta t
$$

式(12)，式(14)，式(15)より，次式が得られる。

$$
\delta \bar{F}_{\phi}=-\int_{D}[f(\phi(x))+\lambda g(\phi(x))]^{2} \delta t \mathrm{~d} \Omega
$$

式(16)より，式(14)と式(15)に基づき微小な時間変分 $\delta t$ に対してレベルセット関数を更新すると, ラグラン ジェアン $\bar{F}_{\phi}$ は単調隇少することがわかる.レベルセ ット関数の変動が収束すれば, レベルセット関数は設 計領域全域において式(13)を満足する。さらに，式 （5）と式(14)を比較すれば, 本最適化問題においては, $V_{N}$ は次式となる.

$$
V_{N}=f(\phi(x))+\lambda g(\phi(x))
$$

また，ラグランジュ乗数入については，制約条件が アクティブである場合， $\delta G_{\phi}=0$ であるので，式 $(9)$, 式(14), 式(15)より, 次式が得られる.

$$
\int_{D} g(\phi(\boldsymbol{x}))[f(\phi(\boldsymbol{x}))+\lambda g(\phi(\boldsymbol{x}))] \delta t \mathrm{~d} \Omega=0
$$

$\delta t$ は時間変分であり, 設計領域全域において共通であ るため, 式(18)よりラグランジュ乗数は次式で与えら れる。

$$
\lambda=-\frac{\int_{D} f(\phi(\boldsymbol{x})) g(\phi(\boldsymbol{x})) \mathrm{d} \Omega}{\int_{D} g(\phi(\boldsymbol{x}))^{2} \mathrm{~d} \Omega}
$$

制約条件がアクティブでない場合には， $\lambda=0$ となる。 このようにラグランジュ乗数を決定し, 式(14)に基づ きレベルセット関数を初期値から更新していき, 変動 が収束したときのレベルセット関数が，最適解とな る.

$2 \cdot 3$ 振動特性最適化問題の定式化 境界 $\Gamma_{u}$ を 完全拘束した設計領域 $D$ において, 線形弾性体が自 由振動している場合を考える。このときの最低次から $k$ 番目の固有振動数を $\omega_{k}$, 固有振動モードを $\boldsymbol{u}_{k}$ と表 せば，次式に示す固有方程式が成立する。

$$
\begin{aligned}
& -\omega_{k}^{2} \int_{D} \rho \boldsymbol{u}_{k} \cdot \boldsymbol{u}_{k} H(\phi(x)) \mathrm{d} \Omega \\
& \quad+\int_{D} \boldsymbol{\varepsilon}\left(\boldsymbol{u}_{k}\right): \boldsymbol{D}: \boldsymbol{\varepsilon}\left(\boldsymbol{u}_{k}\right) H(\phi(\boldsymbol{x})) \mathrm{d} \Omega=0 \cdots
\end{aligned}
$$


を仮定している，Dと $\rho$ は, 線形弾性体の弾性定数 テンソルと質量密度である。また, $H(\phi(x))$ はへビ サイド関数であり, 物体領域において 1 , 空洞領域に おいて 0 をとる.さらに, 通常固有振動モードは,

$$
\int_{D} \rho \boldsymbol{u}_{k} \cdot \boldsymbol{u}_{k} H(\phi(x)) \mathrm{d} \Omega=1
$$

となるように正規化するので, $k$ 番目の固有振動数 $\omega_{k}$ は

$$
\omega_{k}^{2}=\int_{D} \boldsymbol{\varepsilon}\left(\boldsymbol{u}_{k}\right): \boldsymbol{D}: \boldsymbol{\varepsilon}\left(\boldsymbol{u}_{k}\right) H(\phi(\boldsymbol{x})) \mathrm{d} \Omega
$$

として与えられる.

前述のように, 本研究では, より動的に安定な機械 構造物を得るための最低次の固有振動数最大化問題 と, より高い動的機能をもつ機械構造物を得るための 特定の固有振動数を持つ構造を求める問題を考える. なお，これらの問題は別々の構造最適化問題であり， それぞれの場合について, 以下のように目的汎関数を 定式化する。

まず,より動的に安定な構造物を得るために, 最低 次の固有振動数の最大化を考える.このとき目的汎関 数 $F_{\phi}$ は次式となる.

$$
F_{\phi}=-\omega_{1}^{2}
$$

なお，この場合，目的㲸関数の最大化を最小化に置き 換えるため, $\omega_{1}^{2} に$ 負符号を付加し, 目的汎関数として いる.このとき, 文献 (14)によれば $f(\phi(x))$ は次式で 与えられる。

$$
f(\phi(\boldsymbol{x}))=-\left(\varepsilon\left(\boldsymbol{u}_{1}\right): \boldsymbol{D}: \boldsymbol{\varepsilon}\left(\boldsymbol{u}_{1}\right)-\omega_{1}^{2} \rho \boldsymbol{u}_{1} \cdot \boldsymbol{u}_{1}\right) \frac{\mathrm{d} H}{\mathrm{~d} \phi}
$$

次に, 特定の振動数において共振現象を示す機械構 造物を得るために, $s$ 番目の固有振動数 $\omega_{s}$ を目標と する値 $\omega_{o b j, s}$ に一致させる問題を考える.このとき, 目的汎関数 $F_{\phi}$ は次式のように定式化される.

$$
F_{\phi}=\left(\omega_{s}^{2}-\omega_{o b j, s}^{2}\right)^{2}
$$

このとき, $f(\phi(x))$ は次式で与えられる.

$$
\begin{aligned}
& f(\phi(\boldsymbol{x}))=2\left(\omega_{s}^{2}-\omega_{o b j, s}^{2}\right) \\
& \quad \times\left(\boldsymbol{\varepsilon}\left(\boldsymbol{u}_{s}\right): \boldsymbol{D}: \boldsymbol{\varepsilon}\left(\boldsymbol{u}_{s}\right)-\omega_{s}^{2} \rho \boldsymbol{u}_{s} \cdot \boldsymbol{u}_{s}\right) \frac{\mathrm{d} H}{\mathrm{~d} \phi} .
\end{aligned}
$$

他方, 制約汎関数 $G_{\phi}$ は, 上の二つの場合について 物体領域の体積とする.すなわち,

$$
G_{\phi}=\int_{D} H(\phi(x)) \mathrm{d} \Omega
$$

である.このとき, $g(\phi(x))$ は次式で与えられる.

$$
g(\phi(x))=\frac{\mathrm{d} H}{\mathrm{~d} \phi}
$$

$2 \cdot 4$ トポロジカルデリバティブの定式化 レ心゙ ルセット法に基づく最適化法において, 穴の数が増え る形態の変化を起こすために, トポロジカルデリバテ
イブを用いて物体領域に微小な空洞領域を設ける方法 が利用されている(19). トポロジカルデリバティブと は, 物体領域中に微小な空洞領域を設けたときの目的 汎関数の感度であり, レベルセット法を用いて物体形 状を表現する場合, 次式で定義される。

$$
\tau(x)=\lim _{r \rightarrow 0} \frac{F_{\phi+r \delta \phi_{B}(\boldsymbol{x})}-F_{\phi}}{\int_{D}\left[H\left(\phi+r \delta \phi_{B(\boldsymbol{x})}\right)-H(\phi)\right] \mathrm{d} \Omega}
$$

ここで, $r \delta \phi_{B(x)}$ は $x$ において半径 $r$ の空洞領域を設 けるレベルセット関数の変動であり, $\tau(x)$ は $x$ にお けるトポロジカルデリバティブである. 式(29)より次 式が導かれる。

$$
\begin{aligned}
\tau(\boldsymbol{x}) & =\lim _{r \rightarrow 0} \frac{F_{\phi+r \delta \phi_{B(\boldsymbol{x})}}-F_{\phi}}{r} \\
\times & \frac{r}{\int_{D}\left[H\left(\phi+r \delta \phi_{B(\boldsymbol{x})}\right)-H(\phi)\right] \mathrm{d} \Omega} \\
= & \frac{\int_{D} f(\phi) \delta \phi_{B(\boldsymbol{x})} \mathrm{d} \Omega}{\int_{D} \frac{\mathrm{d} H}{\mathrm{~d} \phi} \delta \phi_{B(\boldsymbol{x})} \mathrm{d} \Omega}=\frac{f(\phi)}{\frac{\mathrm{d} H}{\mathrm{~d} \phi}} \text { at } x
\end{aligned}
$$

よって, 最低次の固有振動数最大化問題の場合, 卜ポ ロジカルデリバティブは次式で与えられる.

$$
\tau(\boldsymbol{x})=-\left(\boldsymbol{\varepsilon}\left(\boldsymbol{u}_{1}\right): \boldsymbol{D}: \boldsymbol{\varepsilon}\left(\boldsymbol{u}_{1}\right)-\dot{\omega}_{1}^{2} \rho \boldsymbol{u}_{1} \cdot \boldsymbol{u}_{1}\right) \cdots(31)
$$

また, $s$ 番目の固有振動数 $\omega_{s}$ を目標とする值 $\omega_{o b j, s}$ に一致させる問題の場合, トポロジカルデリバティブ は次式で与えられる。

$$
\begin{gathered}
\tau(\boldsymbol{x})=2\left(\omega_{s}^{2}-\omega_{o b j, s}^{2}\right)\left(\boldsymbol{\varepsilon}\left(\boldsymbol{u}_{s}\right): \boldsymbol{D}: \boldsymbol{\varepsilon}\left(\boldsymbol{u}_{s}\right)\right. \\
\left.-\omega_{s}^{2} \rho \boldsymbol{u}_{s} \cdot \boldsymbol{u}_{s}\right) \ldots \ldots \ldots \ldots \ldots \ldots \ldots \ldots \ldots \ldots \ldots \ldots \ldots \ldots \ldots \ldots \ldots \ldots \ldots \ldots \ldots \ldots
\end{gathered}
$$

物体領域において, トポロジカルデリバティブの絶対 值が 0 に近い箇所に徵小な空洞領域を設けると, 体積 の減少に対する目的汎関数の変化の割合を最小にして 形態変更が可能となる.

そこで本研究では, このトポロジカルデリバティブ の値を用いて, 以下の手続きにより穴を創出すること により, 形態変更を゙行う。まず, 設計領域内にあるレ ベルセット関数の更新に用いる各有限要素の中心点に おいて, トポロジカルデリバティブの値を求める. 次 に, 有限要素の中心点群の中で, 物体境界から十分離 れており, かつトポロジカルデリバティブの值の絶対 值が最小值となる点から小さい順に $n_{t p}$ 個選択する. なお，候補点が物体境界から十分離れているかどうか は, レベルセット関数值が閾值 $b_{t p}$ 以上かどうかで判 断する。そして, 選択した $n_{t p}$ 個の点に対して, 点を 中心とする半径 $r_{t p}$ の穴を設ける. 


\section{3. 最適化法の構築}

$3 \cdot 1$ 最適化アルゴリズム 図1に最適化のフロ 一チャートを示す、最初にレベルセット関数の初期值 を与える. 次に，レベルセット関数に対応する目的沉 関数, $f(\phi(\boldsymbol{x}))$, 制約汎関数, $g(\phi(\boldsymbol{x}))$ を, 有限要素法 を用いて計算する。ここで, 目的沉関数の変動が収束 すれば，最適解が得られたと判断して最適化を終了す る. 収束しない場合, 形態の変更が必要であれば, 卜 ポロジカルデリバティブを用いて形態を変更する，次 に, 式(14)に基づき, 有限要素法を用いてレベルセッ 卜関数を更新する. 更新後に, レベルセット関数の符 号付き距離関数としての性質を確保するために, 再初 期化を行う。レベルセット関数の更新により,制約条 件が満たされなくなる場合，形態を保持したままレべ ルセット関数を修正し(17)，最初のステップに戻る。

$3 \cdot 2$ レベルセット関数の再初期化 本研究にお いて用いるレベルセット関数の再初期化法の基本的な



Fig. 1 Flowchart of optimization procedure
考元方は，筆者らが提案した再初期化法(17) と同一で あるが，実装を容易にするために，物体境界を表現す る点集合を求める方法を以下のように改良した。な お, 本方法はどのような要素においても適用可能であ るがここでは，四角形平面要素と六面体立体要素を 対象として説明する。

四角形平面要素の場合, 図 $2(a)$ に示す一般座標系 から, 図 2(b)に示すパラメトリック座標系への座標 変換を用いて, レベルセット関数 $\phi(r, s)$ を次式で示 す双一次関数で表す。

$$
\phi(r, s)=a_{0}+a_{1} r+a_{2} s+a_{3} r s
$$

ここで, $a_{0}, a_{1}, a_{2}, a_{3}$ は, 各節点の座標值とレ心゙ルセ ット関数値の関係により決定される值である。次に， 図 3 亿示す上うに, 物体境界 $\phi(r, s)=0$ と直線 $r=$ $-1+(2 / n) l$ の交点を求める。ここで, $n$ は 1 以上の 自然数とし，lは 0 から $n$ までの整数とする. 同様に, 物体境界 $\phi(r, s)=0$ と直線 $s=-1+(2 / n) l$ の交点を 求める。な扔, この $n$ の設定により, 再初期化の精度 を調節することができる，すなわち，この値を大きく すれば, 再初期化の精度を向上できるが, 再初期化化 要する時間は增大する，逆に，值を小さくすれば，再 初期化の精度が低下するが, 再初期化に要する時間を 減少させることができる。

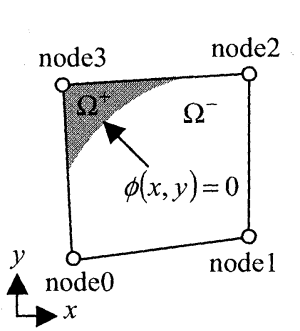

(a) Original coordinate

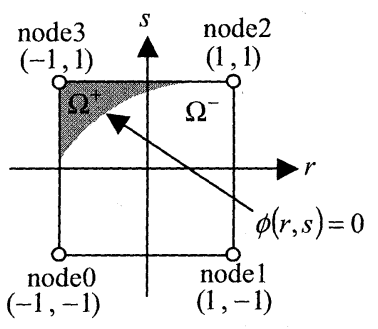

(b) Parametric coordinate
Fig. 2 Element coordinates

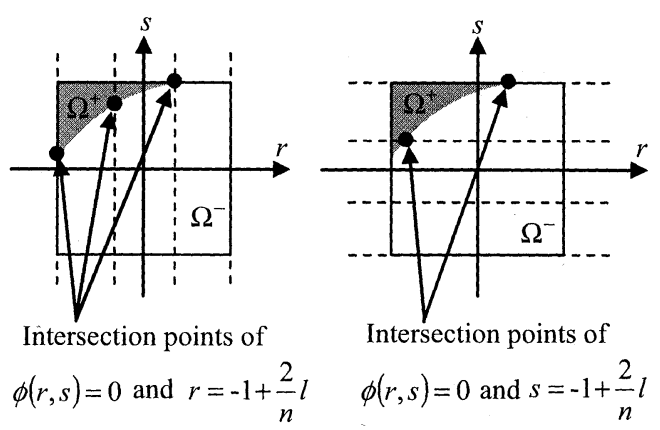

Fig. 3 Intersection points on shape boundary 
六面体立体要素内において, 物体境界を代表する点 を求める場合も同様に, 一般座標系からパラメトリッ ク座標系への座標変換を用いて,レベルセット関数 $\phi(r, s, t)$ を次式で表現する.

$$
\begin{aligned}
& \phi(r, s, t)=a_{0}+a_{1} r+a_{2} s+a_{3} t+a_{4} r s+a_{5} s t \\
& \quad+a_{6} t r+a_{7} r s t
\end{aligned}
$$

$a_{0}$ から $a_{7}$ は, 各節点の座標値とレベルセット関数值 の関係により決定される值である。次に, 物体境界 $\phi(r, s, t)=0$ と直線 $(r, s, t)=[-1+(2 / n) l,-1$ $\left.+(2 / n) l^{\prime}, t\right]$, 直 線 $(r, s, t)=[-1+(2 / n) l, s,-1$ $\left.+(2 / n) l^{\prime}\right]$, 直線 $(r, s, t)=[r,-1+(2 / n) l,-1$ $\left.+(2 / n) l^{\prime}\right]$ との交点を求める.ここで, $l^{\prime}$ は 0 から $n$ までの整数とする.

物体境界と交差する全ての要素について, 上述の方 法を用いて物体境界上に位置する点を求め, 得られた 点集合を，設計領域全域において物体境界を表現する 点集合 $P$ とする. そして設計領域内の全節点におい て, この点集合までの距離を計算し, 再初期化前のレ ベルセット関数值の符号を付与したものを, 再初期化 後のレベルセット関数值とする。すなわち, $i$ 番目の 節点における再初期化後のレベルセット関数值 $\phi_{\text {post }, i}$ は, 節点座標 $\boldsymbol{x}_{i}$, 再初期化前のレベルセット関数值 $\phi_{\text {pre }, i}$ を用いて, 次式で与えられる.

$$
\phi_{\text {post }, i}=\operatorname{sgn}\left(\phi_{\text {pre }, i}\right) \times \inf _{\boldsymbol{p} \in P} d\left(\boldsymbol{x}_{i}, \boldsymbol{p}\right)
$$

ここで, $d\left(\boldsymbol{x}_{i}, \boldsymbol{p}\right)$ は $\boldsymbol{x}_{i}$ と $\boldsymbol{p}$ の距離である.なお, 上 式では, 再初期化の前後で物体境界が変動しない必要 があるため, 再初期化前後で, レベルセット関数の符 号が一致するようにしている。この手続きにより,レ ベルセット関数を再初期化する.

$3 \cdot 3$ レベルセット関数の更新方法 微小時間 $\Delta t$ に対して式(5)を離散化すると, 時刻 $t$ におけるレべ ルセット関数 $\phi_{t}$ と, 微小時間 $\Delta t$ 後のレベルセット 関数 $\phi_{t+\Delta t}$ の関係は, 次式で表現される.

$$
\phi_{t+\Delta t}-\phi_{t}=-\Delta t V_{N}
$$

次に, 式(36)を有限要素法を用いて離散化することに より, レベルセット関数の更新に関する以下の式が得 られる。

$$
\boldsymbol{E}\left\{\phi_{t+\Delta t}-\Phi_{t}\right\}=-\Delta t \boldsymbol{V}_{N}
$$

ここで, $\Phi_{t}$ は時刻 $t$ に扔ける各節点のレベルセット 関数值により構成されるべクトルであり, マトリクス $E$, ベクトル $V_{N}$ は次式で与えられる.

$$
\begin{aligned}
& \boldsymbol{E}=\bigcup_{e=1}^{m} \int_{V e} \boldsymbol{N}^{T} \boldsymbol{N} \mathrm{d} V \\
& \boldsymbol{V}_{N}=\bigcup_{e=1}^{m} \int_{V e} V_{N} \boldsymbol{N} \mathrm{d} V .
\end{aligned}
$$

ここで, $\boldsymbol{N}$ はレベルセット関数の補間関数, $m$ は要素
数であり, $\bigcup_{e=1}^{m}$ は要素の重㸚合わせを意味している.

式(37)より, ベクトル $\boldsymbol{E}^{-1} \boldsymbol{V}_{N}$ の $j$ 番目の成分を $\left\{\boldsymbol{E}^{-1} \boldsymbol{V}_{N}\right\}_{j}$ と表現すると, $j$ 番目の節点におけるレベル セット関数值の変化量は $-\Delta t\left\{\boldsymbol{E}^{-1} \boldsymbol{V}_{N}\right\}_{j}$ となる. 上 って, 一回の更新に扔けるレベルセット関数值の量大 変化量を $\mathrm{d} \phi_{\text {lim }}$ とすると, 次式が成り立つ。

$$
\mathrm{d} \phi_{\text {lim }}=\Delta t \max _{j}\left|-\left\{\boldsymbol{E}^{-1} \boldsymbol{V}_{N}\right\}_{j}\right|
$$

式(39)により $\Delta t$ を決定し, 式(37)に基づきレベルセ ット関数を更新する.

$3 \cdot 4$ 実装の詳細 本研究では, へビサイド関数 $H(\phi)$ を次式で示す関数 $H_{D}(\phi)$ で近似ずる.

$$
H_{D}(\phi)= \begin{cases}d, \quad & (\bar{\phi}<-1) \\ \frac{1+d}{2}+\left(\frac{15}{16} \bar{\phi}-\frac{5}{8} \bar{\phi}^{3}+\frac{3}{16} \bar{\phi}^{5}\right)(1-d), & (-1 \leq \bar{\phi} \leq 1) \\ 1, \quad & (1<\bar{\phi})\end{cases}
$$

なお, $\bar{\phi}=\phi / h て ゙ あ り, h$ はへビサイド関数を微分可 能にするため導入する, へビサイド関数の遷移幅であ る. $d$ は固有値問題を有限要素法を用いて安定的に解 くための, 十分に小さい正の值である.

上の hの値は, 最適形状の滑らかさに大きな影響を 与える.すなわち, hをより大きな値に設定すれば, 滑らかな最適形状が得られるが, 詳細な構造の表現が 難しくなる。この問題を解決するため, 本研究では, 筆者らが提案した $H(\phi(x))$ フィルタ ${ }^{(20)}$ を, 振動特性 最適化問題に適用する。すなおち, 式(24), 式(26)に おいて, $\boldsymbol{\varepsilon}: \boldsymbol{D}: \varepsilon$ を $(\boldsymbol{\varepsilon}: \boldsymbol{D}: \boldsymbol{\varepsilon}) H_{D}(\phi(\boldsymbol{x}))$ に置き換え た $f(\phi(\boldsymbol{x}))$ を用いる.これにより, 後の数值例に示す ように, $h$ を, レベルセット関数を更新する際に用い る有限要素の要素長程度の小さな値に設定しても, 詳 細な構造が表現され，かつ滑らかな最適形状が得られ る.なお,この $H(\phi(x))$ フィル夕の詳細については, 文献 (20)を参照されたい.

$3 \cdot 5$ ローカライズドモードの回避法、ヘビサイ ド関数の近似により設計領域を表現すれば, 空洞領域 においてヤング率 $E$ と質量密度 $\rho$ は 0 ではなく十分 小さい正の值となる。これに対して, 空洞領域の固有 振動数は $\sqrt{E / \rho}$ に比例するので, ヤング率と質量密度 が十分小さな值となっても，空洞領域の局所的な領域 に扔いて, 比較的低い固有振動数を持つ物理的に意味 のないローカライズドモード(16)が生じる. 本研究で は，このローカライズドモードを回避するために, 式 (20), 式(21), 式(24), 式(26)に扔ける質量密度に関 するへビサイド関数を $H_{D}(\phi)^{2}$ で近似する。これによ 
り,ローカライズドモードの固有振動数は $\sqrt{1 / H_{D}(\phi)}$ に比例し, かつ, 空洞領域では $H_{D}(\phi)$ は十分小さい正 の值 $d$ であるので, ローカライズドモードの固有振動 数は対象としている物体領域に扔ける固有振動数と比 較して十分に高い振動数領域に出現することになり， ローカライズドモードが回避される.

\section{4. 数 值 例}

幾つかの平面応力状態を想定した二次元の振動特性 最適化問題を解くことにより, 本研究で提案する最適 化法の有用性を検証する。

図 4 亿設計領域と境界条件を示す。設計領域の左辺 と右辺を完全拘束し, 中央部分に $0.16 \mathrm{~kg}$ の質点を設 定する. 図 5 に初期形状を示す. 図中灰色の領域が物 体領域, 白色の領域が空洞領域である。ここでは, 図 5(a)の設計領域が構造メッシュで構成される場合と, 図 5(b)の非構造メッシュで構成される場合を用意す る. 設計領域を構成する要素には双一次近似アイソパ ラメトリック四角形平面応力要素を用い, 図 5(a),

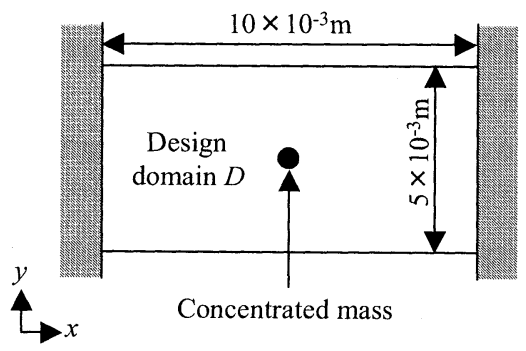

Fig. 4 Design domain and boundary condition

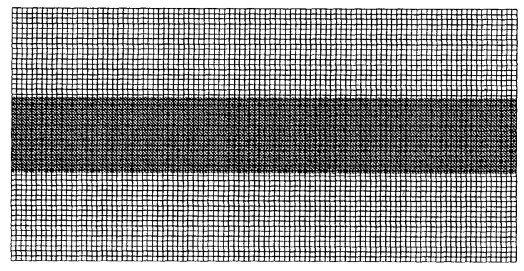

(a) Structural mesh

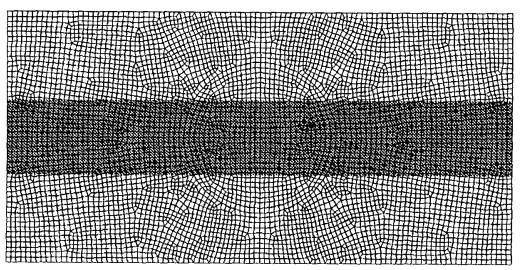

(b) Non-structural mesh

Fig. 5 Initial configurations (b) とも, 平均要素長が $1.0 \times 10^{-4} \mathrm{~m}$ となるように設 計領域を要素分割している。また，図の物体領域は， ヤング率 $2.1 \times 10^{5} \mathrm{MPa}$, ポアソン比 0.3 , 質量密度 $7800 \mathrm{~kg} / \mathrm{m}^{3}$ の線形弾性体で構成されているものとす る.そして, へビサイド関数が 0 から 1 へ遷移する際 の幅 $h$ を $1.0 \times 10^{-4} \mathrm{~m}$, ヘビサイド関数の定義に用い る十分小さな值 $d$ を $1.0 \times 10^{-6}$ とする. また, 再初期 化の設定で用いるパラメータ $n$ については, 多くの数 值実験から 8 に設定することにより, 十分短い計算時 間で，かつ精度よく再初期化を行えることがわかった ため, 本数值例では $n$ を 8 に設定する.さらに, 物体 領域の体積の上限值 $G_{\max }$ を $1.5 \times 10^{-5} \mathrm{~m}^{2}$ とし, 最適 化を図る。

他方, トポロジカルデリバティブに基づく形態変更 に必要なパラメータについては, 一回の形態変更で設 ける穴の個数 $n_{t p}$ を 4 に, 穴の半径 $r_{t p}$ を平均要素長, すなわち $1.0 \times 10^{-4} \mathrm{~m}$ に, ある点が物体境界から十分 に離れているかどうかを判断するための閾值パラメー 夕 $b_{t p}$ を平均要素長の 3 倍, すなわち $3.0 \times 10^{-4} \mathrm{~m}$ に 設定する.

設計領域が構造メッシュで構成される場合も非構造 メッシュで構成される場合も, 初期形状における最低 次の固有振動数は $1189 \mathrm{~Hz}$, 二番目の固有振動数は $4077 \mathrm{~Hz}$, 三番目の固有振動数は $14052 \mathrm{~Hz}$ であっ た.また以下に, 最適化の結果を示すが, どの数值例 においても, 最適化の過程において固有振動モードの 入れ替えは生じなかった。



Fig. 6 Optimal configuration of eigenfrequency maximization problem obtained using structural mesh

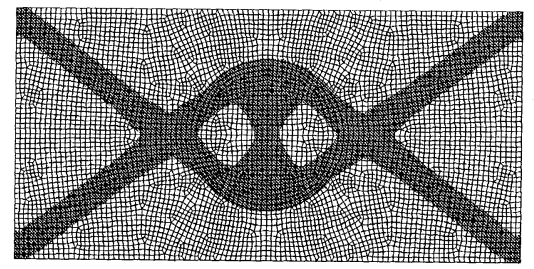

Fig. 7 Optimal configuration of eigenfrequency maximization problem obtained using non-structural mesh 


\section{$4 \cdot 1$ 最低次の固有振動数最大化問題 最初に,} 最低次の固有振動数を最大化する場合について, 最適 構造を求める.なお,ここでは, 式(39)のレベルセッ 卜関数値の最大変化量 $\mathrm{d} \phi_{\text {lim }}$ は $1.0 \times 10^{-4} \mathrm{~m}$ で一定と する. 図 6 亿, 設計領域が構造メッシュで構成される 場合の最適構造を, 図 7 亿, 非構造メッシュで構成さ れる場合の最適構造を示す.設計領域が構造メッシュ で構成される場合, 最適構造の最低次の固有振動数は $2055 \mathrm{~Hz}$ となり, 設計領域が非構造メッシュで構成さ れる場合, 最適構造の最低次の固有振動数は $2048 \mathrm{~Hz}$ となった。図 8 に, 比較のため, トポロジカルデリバ ティブを用いて形態変更を行わなかった場合に得られ た最適構造を示す。この場合, 最適構造の固有振動数 は $1432 \mathrm{~Hz}$ となった。また，これら全ての最適構造 においては, 体積制約はアクティブとなった。

図 6 と図 7 より, 本研究で提案する方法によりメッ シュ分割に依存せずに最適構造が得られることがわか る.さらに,これらの最適構造では, 設計領域に二つ の孔をもつ $y$ 方向に幅もつ構造が創出していること もわかる.この場合の最低次の固有振動モードは, 設 計領域の中心腹をもつ $y$ 方向の一次曲げモードで あるが，この構造により腹部分の剛性が向上し，最低 次の固有振動数は高くなっていると考えられる。な お, Allaire と Jouve が提案した方法(14)では, 前述の ようにレベルセット関数の更新に有限差分法を用いて おり, 基本的に構造メッシュを必要とするので, 図 6 の最適構造しか得られない.これに対して, 本研究で 提案する方法では, レベルセット関数の更新に有限要 素法を用いているので, 図 7 の最適構造も得られるこ とを注記しておく。

また, 図 8 より, 形態変更を行わなかった場合には, 形態変更を行った場合より腹部分の剛性が向上しない ため, 最低次の固有振動数は, 形態変更を行った場合 ほど高くならなかったと考元られる，以上，固有振動 数最大化の場合には, トポロジカルデリバティブによ る形態の変更を行った方が,より固有振動数が高い最

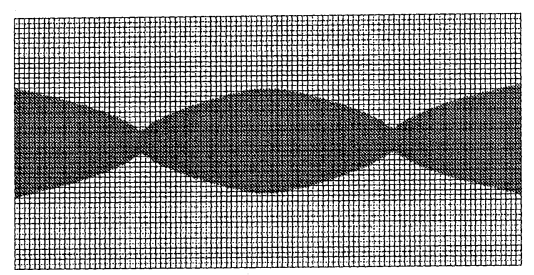

Fig. 8 Optimal configuration of eigenfrequency maximization problem (obtained without topological changes using topological derivatives)

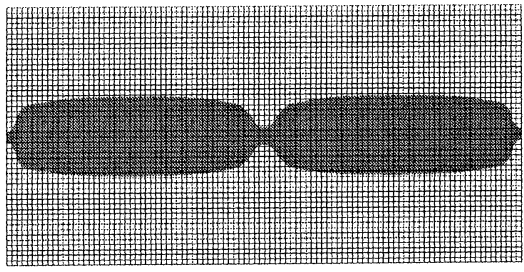

(a) 1st eigenfrequency target value $=300 \mathrm{~Hz}$ (volume $=1.33 \times 10^{-5} \mathrm{~m}^{2}$ )



(b) 1st eigenfrequency target value $=600 \mathrm{~Hz}$ $\left(\right.$ volume $\left.=1.36 \times 10^{-5} \mathrm{~m}^{2}\right)$

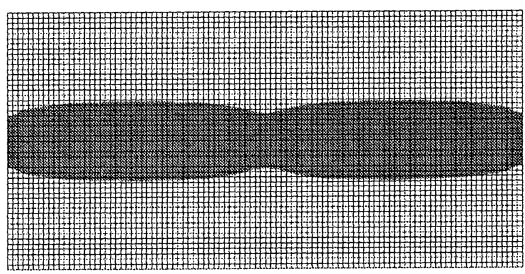

(c) 1 st eigenfrequency target value $=900 \mathrm{~Hz}$ (volume $=1.41 \times 10^{-5} \mathrm{~m}^{2}$ )

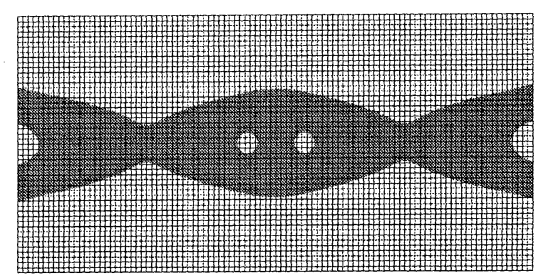

(d) 1st eigenfrequency target value $=1500 \mathrm{~Hz}$ $\left(\right.$ volume $\left.=1.50 \times 10^{-5} \mathrm{~m}^{2}\right)$

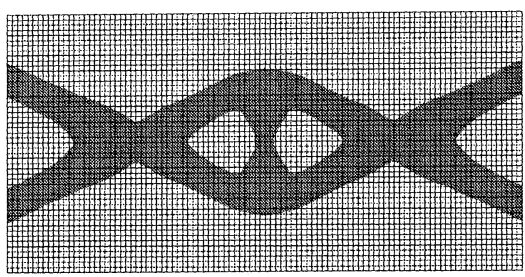

(e) 1st eigenfrequency target value $=1800 \mathrm{~Hz}$ $\left(\right.$ volume $\left.=1.50 \times 10^{-5} \mathrm{~m}^{2}\right)$

Fig. 9 Optimal configurations whose 1st eigenfrequencies are specified target values 


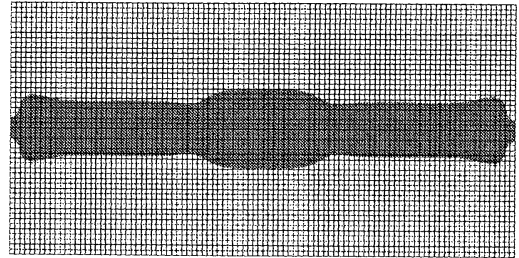

Fig. 10 Optimal configuration whose 2nd eigenfrequency target value is set to $3500 \mathrm{~Hz}$

適構造が得られる可能性が高いと考えられる.

$4 \cdot 2$ 特定の固有振動数を持つ構造を求める問題

次に, 設定した特定の固有振動数をもつ構造を求め る.なお,ここでは, 式(39)のレベルセット関数值の 最大変化量 $\mathrm{d} \phi_{\text {lim }}$ は $1.0 \times 10^{-4} \mathrm{~m}$ を初期値とし, 最適 値近傍に達した段階における目的汎関数の最適値への 収束性を向上させるため, 固有振動数が目標値に近付 くにつれて十分に小さくした。

図 9 に, 最低次の固有振動数を特定の值に設定した 場合の最適構造を示す。図 $9(\mathrm{a}),(\mathrm{b}),(\mathrm{c}),(\mathrm{d})$, (e) は, 最低次の固有振動数をそれぞれ $300 \mathrm{~Hz}, 600$ $\mathrm{Hz}, 900 \mathrm{~Hz}, 1500 \mathrm{~Hz}, 1800 \mathrm{~Hz}$ に設定した場合であ る.なお, この場合に, 最適構造の最低次の固有振動 数はそれぞれ, $300 \mathrm{~Hz}, 600 \mathrm{~Hz}, 900 \mathrm{~Hz}, 1496 \mathrm{~Hz}, 1$ $799 \mathrm{~Hz}$ となった. これらより, どの固有振動数の場 合においても, 物理的に意味のある明瞭な構造が得ら れていることがわかる. そして, 最低次の固有振動数 を $300 \mathrm{~Hz}, 600 \mathrm{~Hz}, 900 \mathrm{~Hz}$ に設定した場合には, 体 積制約は非アクティブとなっているうえ, 形態の変更 はない.これに対して, 最低次の固有振動数を 1500 $\mathrm{Hz}, 1800 \mathrm{~Hz}$ に設定した場合, 体積制約はアクティ ブとなっているうえ, 構造物の形態は変更されてい る.すなわち, 最低次の固有振動数について, 此較的 低い値に設定した場合には, 固有振動数の変更に体積 の増加を必要としないが, 形態変更を行わなかった場 合の最大值である $1432 \mathrm{~Hz}$ を越える設定では, 形態 変更と体積の増加を必要とすることがわかる.

次に, 二次, 三次の固有振動数を設定した場合につ いて最適構造を求める. 図 10 に, 二次の固有振動数 を $3500 \mathrm{~Hz}$ に設定した場合の最適構造を, 図 11 に, 三次の固有振動数を $7000 \mathrm{~Hz}$ に設定した場合の最適 構造を示す.なお, これらの最適構造の二次, 三次の 固有振動数はそれぞれ, $3500 \mathrm{~Hz}, 7002 \mathrm{~Hz}$ となっ た.これより, 二次, 三次の固有振動数を設定した場 合においても, 特定の固有振動数を持ち, 物理的に意 味のある明瞭な構造が得られていることがわかる。

以上の結果から, 本研究で提案する方法により, 変

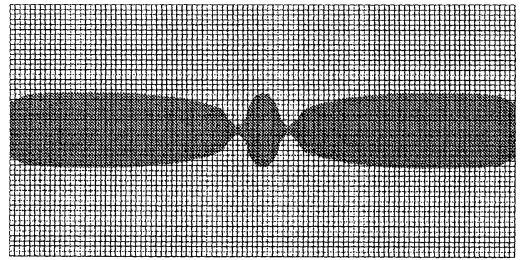

Fig. 11 Optimal configuration whose 3nd eigenfrequency target value is set to $7000 \mathrm{~Hz}$

更可能な範囲内でどのように固有振動数の目標值を設 定しても, 物理的に意味のある明瞭な構造が得られる ことがわかった。

\section{5. 結言}

本研究では, 機械構造物の振動特性最適化問題に対 して, レベルセット法を用いた新しい最適化法を開発 した。結果を以下に示す。

（1）最低次の固有振動数最大化問題と, 特定の固 有振動数を持つ構造を求める問題について, レベルセ ット法に基づく最適化問題を定式化するとともに，両 問題についてトポロジカルデリバティブを導出した

（2）二つの問題のその定式化に基づき，トポロジ カルデリバティブに基づき形態の変更を可能にする最 適化アルゴリズムを構築した. さらに, 筆者らが提案 するレベルセット関数の再初期化法を, 従来よりも実 装が容易な方法に改良するとともに，へビサイド関数 の近似法に改良を加えることにより，ローカライズド モードを回避する方法を提案した。

（3）簡単な数値例により, 本研究で提案する方法 の有効性を検証した. その結果, 本方法においては, メッシュ分割に依存せずに物理的に妥当で, 明瞭な最 適構造が得られることがわかった。さらに, トポロジ カルデリバティブに基づき形態の変更を行なった方 が, 固有振動数をより広い範囲において設定可能であ ることがわかった。

なお，本研究は，(財) みずほ学術振興財団の助成の もとに実施した。本援助に深く謝意を表する。

\section{文献}

(1) Ma. Z. D., Kikuchi, N. and Cheng, H. C., Topological design for vibrating structures, Computer Methods in Applied Mechanics and Engineering, Vol.121 (1995), pp. 259-280.

(2) Diaz, A. R. and Kikuchi, N., Solutions to shape and topology eigenvalue optimization using a homogenization method, International Journal for Numerical Methods in Engineering, Vol. 35 (1992), pp. 1487-1502.

(3) Jose, K. A., Suh, W. D., Xavier, P. B., Varadan, V. K. 
and Varadan, V.V., Surface acoustic wave MEMS gyroscope, Wave Motion, Vol. 36 (2002), pp. 367-381.

(4) Saitou, K., Wang, D. A. and Wou, S. J., Externally resonated linear microvibromotor for microassembly, Journal of Microelectromechanical Systems, Vol. 9 (2000), pp. 336-346.

(5) Bendsøe, M. P. and Kikuchi, N., Generating optimal topologies in structural design using a homogenization method, Computer Methods in Applied Mechanics and Engineering, Vol. 71 (1988), pp. 197-224.

(6) Wu, C. Z., Azegami, H., Shimoda, M. and Sakurai, T., Domain optimization analysis in natural vibration problems (Mass minimization problems), Transactions of the Japan Society of Mechanical Engineers, Series C, Vol. 61, No. 587 (1995), pp. 49-54.

(7) Nishiwaki, S., Saitou, K., Min, S. and Kikuchi, N., Topological design considering flexibility under periodic loads, Structural Optimization, Vol. 19 (2000), pp. 4-16.

(8) Tcherniak, D., Topology optimization of resonating structures using SIMP method, International Journal for Numerical Methods in Engineering, Vol. 54 (2002), pp. 1605-1622.

(9) Maeda, Y., Nishiwaki, S., Izui, K., Yoshimura, M., Matsui, K. and Terada, K., Structural topology optimization of vibrating structures with specified eigenfrequencies and eigenmode shapes, International Journal for Numerical Methods in Engineering, Vol. 67 (2006), pp. 597-628.

(10) Sethian, J. A. and Wiegmann, A., Structural boundary design via level set and immersed interface methods, Journal of Computational Physics, Vol. 163 (2000), pp. 489-528.

(11) Wang, M. Y., Wang, X. and Guo, D., A level set method for structural topology optimization, Computer Methods in Applied Mechanics and Engineering, Vol. 192 (2003), pp. 227-246.

(12) Allaire, G., Jouve, F. and Toader, A. M., Structural optimization using sensitivity analysis and a level-set method, Journal of Computational Physics, Vol. 194 (2004), pp. 363-393.

(13) Céa, J., Garreau, S., Guillaume, P. and Masmoudi, M., The shape and topological optimizations connection, Computer Methods in Applied Mechanics and Engineering, Vol. 188 (2000), pp. 713-726.

(14) Allaire, G. and Jouve, F., A level-set method for vibration and multiple loads structural optimization, Computer Methods in Applied Mechanics and Engineering, Vol. 194 (2005), pp. 3269-3290.

(15) Osher, S. and Santosa, F., Level set methods for optimization problems involving geometry and constraints I. frequencies of a two-density inhomogeneous drum, Journal of Computational Physics, Vol. 171 (2001), pp. 272-288.

(16) Pedersen, N.L., Maximization of eigenvalues using topology optimization, Structural and Multidisciplinary Optimization, Vol. 20 (2000), pp. 2-11.

(17) Yamasaki, S., Nishiwaki, S., Izui, K. and Yoshimura, M., Structural optimization of mechanical structures based on the level set method (Construction of a new re-initialization method and its application to the stiffness maximization problem), Transactions of the Japan Society of Mechanical Engineers; Series C, Vol. 73, No. 725 (2007), pp. 72-79.

(18) Sethian, J.A., Level set methods and fast marching methods, (1999), pp. 112-113, Cambridge University Press.

(19) Allaire, G., Gournay, F., Jouve, F. and Toader, A. M., Structural optimization using topological and shape sensitivity via a level set method, Control and Cybernetics, Vol. 34 (2005), pp. 59-80.

(20) Yamasaki, S., Nishiwaki, S., Izui, K. and Yoshimura, M., Structural optimization based on the level set method using topological derivatives, Transactions of the Japan Society for Computational Engineering and Science, Vol. 2007 (2007), No. 20070009. 